\title{
A systematic review: effectiveness of mass media campaigns for reducing alcohol-impaired driving and alcohol-related crashes
}

\author{
Rajendra-Prasad Yadav ${ }^{*}$ and Miwako Kobayashi
}

\begin{abstract}
Background: Mass media campaigns have long been used as a tool for promoting public health. In the past decade, the growth of social media has allowed more diverse options for mass media campaigns. This systematic review was conducted to assess newer evidence from quantitative studies on the effectiveness of mass media campaigns for reducing alcohol-impaired driving (AID) and alcohol-related crashes, particularly after the paper that Elder et al. published in 2004.

Methods: This review focused on English language studies that evaluated the effect of mass media campaigns for reducing AID and alcohol-related crashes, with or without enforcement efforts. A systematic search was conducted for studies published between January 1, 2002 and December 31, 2013. Studies from the review by Elder et al. were added as well.

Results: A total of 19 studies met the inclusion criteria for the systematic review, including three studies from the review by Elder et al. Nine of them had concomitant enforcement measures and did not evaluate the impact of media campaigns independently. Studies that evaluated the impact of mass media independently showed reduction more consistently (median $-15.1 \%$, range -28.8 to $0 \%$ ), whereas results of studies that had concomitant enforcement activities were more variable (median $-8.6 \%$, range -36.4 to $+14.6 \%$ ). Summary effects calculated from seven studies showed no evidence of media campaigns reducing the risk of alcohol-related injuries or fatalities (RR 1.00, $95 \% \mathrm{Cl}=0.94$ to 1.06).

Conclusions: Despite additional decade of evidence, reviewed studies were heterogeneous in their approaches; therefore, we could not conclude that media campaigns reduced the risk of alcohol-related injuries or crashes. More studies are needed, including studies evaluating newly emerging media and cost-effectiveness of media campaigns.
\end{abstract}

\section{Background}

The World Health Organization (WHO) estimates that the number of people killed in road traffic crashes is about 1.2 million per year, and the number injured is as high as 50 million per year [1]. Over $90 \%$ of road traffic deaths occur in low-income and middle-income countries. Alcohol is found to be present in 33-69 \% of fatally-injured drivers, and 8-29\% of non-fatally injured drivers [2].

\footnotetext{
* Correspondence: yadavr@who.int

Stop TB Unit, World Health Organization Representative Office in Cambodia, No 177-179 Street Pasteur and 254, Sangkat Chak Tomouk, Khan Daun Penh, Phnom Penh, Cambodia
}

Mass media campaigns has long been used as a tool for promoting public health, and their effectiveness have been assessed and described in different literature [3]. Some studies linked with successful campaigns are those focusing on adoption of new behaviors as compared with prevention or cessation of problem behaviors, or those that had concomitant law enforcement aspects [3, 4]. Among media campaigns focusing on prevention or reduction of substance use, data shows that campaigns focusing on alcohol use may be more successful than campaigns focusing on illicit drugs or tobacco $[3,5]$.

Many countries around the world have been using the triangle of legislation-enforcement-publicity for effective 
social marketing campaigns against alcohol-impaired driving (AID) [6]. High visibility enforcements of legislation generally utilize a combination of high-fear emotive advertising to change attitude and low-fear informational advertising to change knowledge [7]. In 2004, Elder et al. published a systematic review on the effectiveness of mass media campaigns for reducing AID and alcohol-related crashes [8]. The results showed that, overall, media campaigns lead to a median decrease in alcohol-related crashes of $13 \%$ (interquartile range: 6 to $14 \%$ ).

Traditionally, media have been categorized into three types: paid, earned, and owned [9]. Paid media include traditional advertising, where an advertiser pays for space or for a third party to promote something that the advertiser wants to draw attention to. Examples include TV commercials and magazine and newspaper advertisements. Earned media are publicity you get for free such as by news coverage or when the public spread information through external or their own media at no cost to yourself. Owned media consists of properties or channels owned by the advertiser that uses them for the purpose of promotion. Examples include websites or brochures created and owned by the advertiser. Mass media campaigns have usually used a combination of these media types. During the past decade, the Internet has rapidly developed, and social media have become one of the most popular Internet services in the world [10]. It has been used in health promotion campaigns as well, although reports have shown variable outcomes [11-13]. With the availability of wider options to deliver media campaigns, we considered that new evidence might be available in the effectiveness of mass media campaigns in reducing AID since the paper that Elder et al. published in 2004.

\section{Objectives}

The primary objective of this systematic review is to assess available evidence from quantitative studies after the review by Elder et al. [8] on the effectiveness of mass media campaigns with or without concomitant enforcement activities for reducing AID and alcohol-related crashes compared to no media interventions among drivers of any type of motor vehicle on public roads in any country, state, or community. See the logical framework in Fig. 1, which guided the review.

\section{Methods}

\section{Eligibility criteria}

Types of studies included experimental, quasi-experimental and observational. The language was limited to English. Only papers published after January 2002 were considered. Population included all drivers of any type of motor vehicle on public roads, of any gender and of all ages. Any lengths of follow-up were included. Settings included any country, state or community of any size. Interventions included any type of mass media used for reducing AID, with or without enforcement efforts. Comparators included any type of control or comparison group or area not exposed to the campaign and with no changes in legislation, enforcement or publicity during the period of the study. Studies without comparator groups were also included.

Primary outcome measures included alcohol-related crashes and alcohol-related crash injuries and fatalities. Secondary outcome measures were used as surrogates for primary outcome measures but only if the latter were unavailable. These included single-vehicle-night-time crashes, all nighttime crashes, all single vehicle crashes and all crashes. Blood alcohol concentrations measured at sobriety points and interview reports of target populations were excluded as outcome measures because of the potential to be biased due to police's and target populations' knowledge of the intervention, respectively [14]. If the study did not provide specific figures for the outcome measures, it was excluded from analysis.

\section{Search strategy}

The review searched the following computerized databases: PubMed, Ovid Medline, EMBASE, Psych Info, Transport Research International Documentation (TRID), Scopus, and Global Health.

The search syntax that this review used was: (mass media or television or TV or radio or cinema or movie*

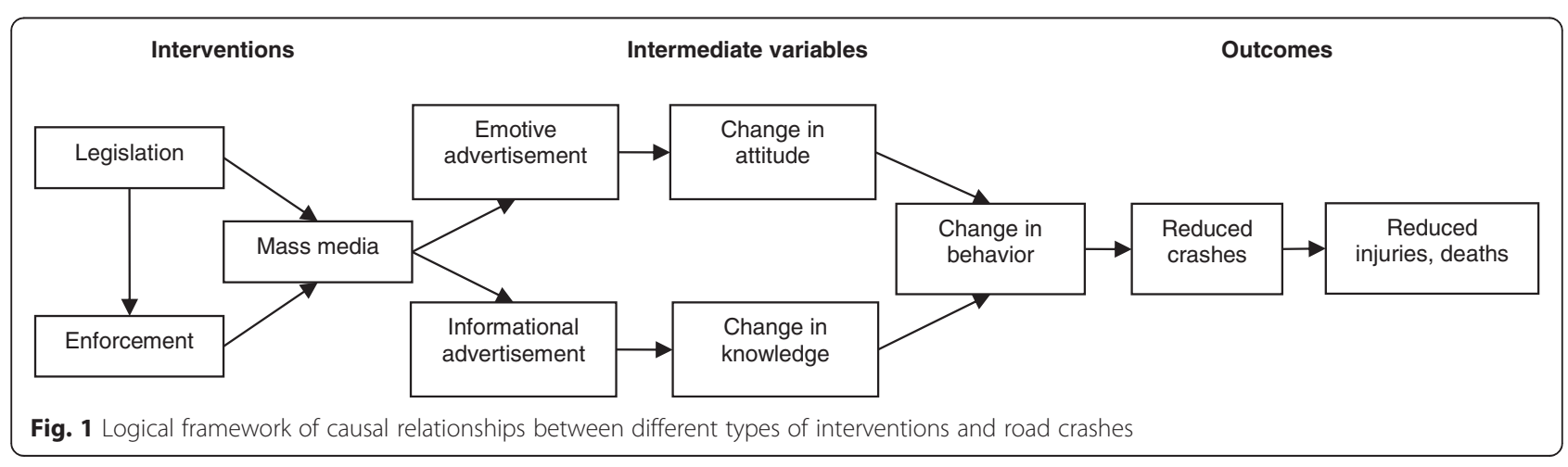


or film* or social media or social network ${ }^{*}$ or publicity campaign or campaign" or market*) and ((alcohol or beer or wine or spirit*) and (drink* or intoxicat* or intake or consum*) and (automobile* or car or cars or road or traffic or truck* or driving or driver*) and (crash* or accident" or collision*). In addition to this syntax, the review 'exploded' database-specific MeSH terms if the databases supported this.

The searches were limited to publications in English language. Since this review was intended to be an update of the review by Elder et al. in 2004 [8], which had reviewed relevant studies published until 31 December 2001, the literature searches for this review were set from January 1, 2002 to "current" (31 December 2013). In addition, this review included all studies of Elder 2004 [8] except the study by McLean et al. [15] which had an outcome measure of blood alcohol concentration, which does not fit the eligibility criteria of this review.

\section{Study selection}

The two reviewers (MK and RY) independently examined titles, abstracts and key works of citations from electronic databases for eligibility. The reviewers tried to err on the side of over-inclusion during this stage. For studies that appeared to meet the inclusion criteria, or in cases when a definite decision could not be made based on the title or abstract alone, the full text were obtained for detailed assessment against the inclusion criteria. For manuscripts that could not be obtained, an attempt was made to contact the authors for information. Studies were excluded at this stage if they failed on one or more criteria. Reasons were recorded for the exclusions. The selection was done using the software EPPI-Reviewer 4, version 4.3.6.0.

\section{Data collection process and data items}

Once studies were selected, data was extracted using a standard form developed for this review. Extracted data items included study objectives, methods, participants, follow-up period, settings, interventions, and outcomes.

\section{Summarizing outcome measures}

Whenever available, alcohol-related fatal crashes were used as the outcome and figures between the intervention group and control group were compared. Unless a model was used (e.g. regression models or Autoregressive Moving Average Model (ARIMA) for interrupted time series (ITS) studies) that calculated the degree of change during the study period, the changes in individual studies were calculated using the difference in pre- and post- intervention means. The summary effects from all included studies were described using the median and the range. Since proxy measures were used in some studies, the following order of priority was used to select the outcome measures: single-vehicle-night-time crashes, all-night-time crashes, all-single vehicle crashes, and all crashes. Use of fatal crashes were given priority over nonfatal injury crashes, as fatal nighttime crashes is considered as a validated surrogate for alcohol-related fatalities [16].

\section{Summary effects measures calculation}

Given the heterogeneity in the outcome measures used in the studies, for the purpose of summary effects measures calculation, we selected studies that allowed us to calculate the relative risk of alcohol-related fatal crashes among all crashes pre- and post-intervention. If information on total number of crashes was not available, alternative measurements (e.g. fatal crashes among drivers in the campaign target population with $\mathrm{BAC} \geq 0.08 \mathrm{~g} / \mathrm{dL}$ versus all alcoholrelated fatalities) were selected to help control for the overall trend in total crashes and other factors that may influence the total number of crashes [8]. We estimated pooled relative risks using the random-effects model. Review Manager 5.2 (version 5.2.4) was used for this analysis.

\section{Assessment of risk bias}

Assessment of the risk bias in individual studies at the study as well as outcome levels was done to determine the methodological quality of the included studies. For this purpose, this review used the guidelines provided by the EPOC checklist [17], and classified the studies into "good quality", "intermediate quality" and "low quality". If the study did not use any model for analysis, it was considered as a low-quality study. Also, if the measured effects were inclusive of interventions other than mass-media (e.g. other enforcement measures or educational activities), the study was considered as intermediate quality at its best.

\section{Results}

Study selection

See Fig. 2. All searches yielded 868 titles. First, all duplicates were removed to yield 675 studies. Thereafter, 647 studies were removed based on titles and abstracts to yield 28 studies. Full-text articles were reviewed for the 28 titles for topic, language, interventions and outcomes. This yielded 16 studies, and were included in this review in addition to three studies from Elder [8].

\section{Study characteristics}

The study characteristics are summarized in Tables 1 and 2 .

\section{Study design}

Of the 19 included studies [18-36], nine were controlled interrupted time series (CITS) [18, 19, 23-26, 31, 32, 36], seven were uncontrolled interrupted time series (ITS) [20, 


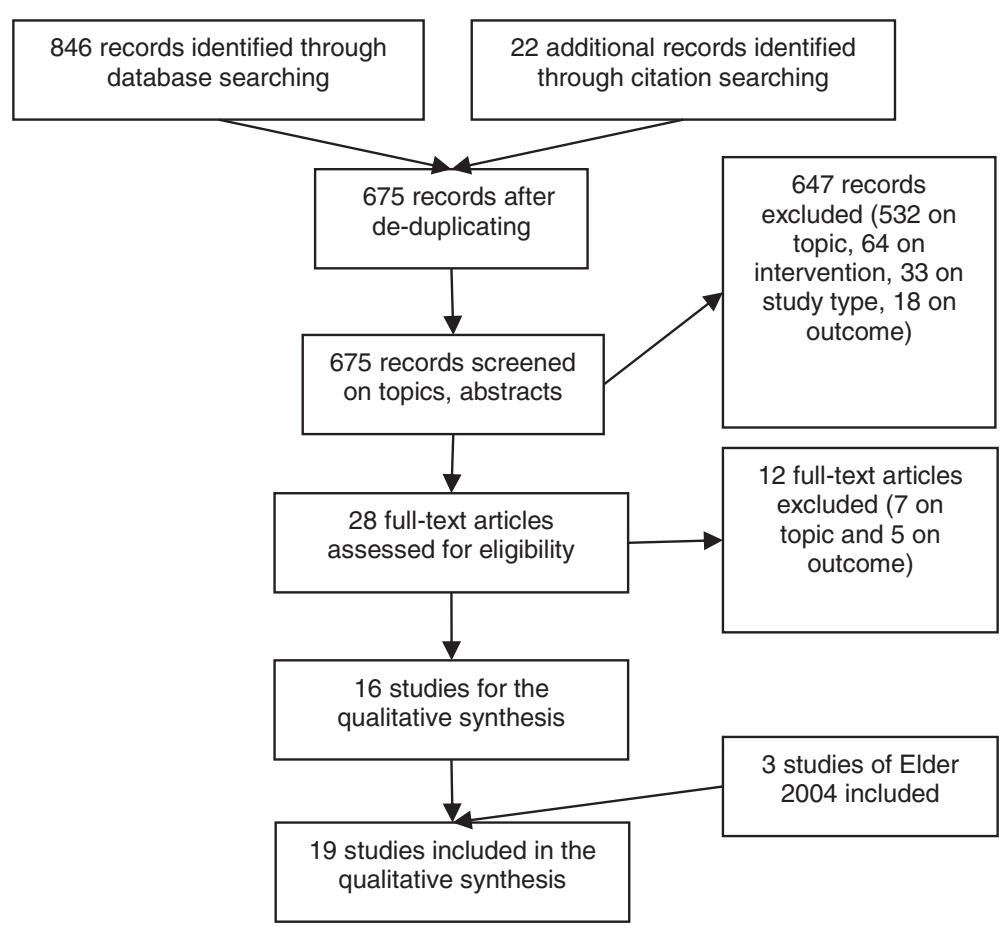

Fig. 2 Flow diagram of study selection

$21,27-30,33]$ and three were controlled before-after studies (CBA) [22, 34, 35]. Nine [23-28, 31-33] of the studies had concomitant enforcement activities taking place at the time of the media campaign and the effect of the media campaign was not analyzed separately.

\section{Participants}

Seven studies $[18,19,21,22,25,28,32]$ specified a target age group for their media campaigns, ranging from 15 to 34 years of age. One study [26] summarized a mixture of media campaigns that had both target age groups and no target age groups. The rest targeted drivers of all ages.

\section{Settings}

There was one study each from Thailand [33], Italy [34], and Australia [20]. Three were from New Zealand [21, $30,36]$, and the rest were from the US.

\section{Interventions}

Media activities included advertisements in newspaper, radio, broadcast and cable television, cinema, billboards, posters, banners, stickers, with a combination of paid and earned media. There were no projects that explicitly described the use of social media in their campaigns. Those that had concomitant enforcement activities included interventions such as speed cameras, compulsory breath testing, sobriety checkpoints and patrols, changes in speed limits, driving under the influence (DUI) legislation or drinking age. Three studies [22, 23, 34] had a supplementary education program in the target community, including workplace [22] and school [34].

\section{Comparator}

Eleven studies [18, 19, 22-26, 31, 32, 35, 36] defined a comparator. One study used different hours in the day ("high alcohol consumption hours" and "low alcohol consumption hours") for comparison [36]. The rest either compared different counties within the same state $[18,22-24,35]$, neighboring states $[19,25,31,32]$, or data from the entire nation [26].

\section{Outcome measures}

Eight studies [23-28, 31, 32] used alcohol-related fatal crashes as outcome measures. The rest used proxy measures for outcome (Fig. 3).

\section{Quality measures and risk of bias}

See Tables 3 and 4. Based on the results of quality assessment, four studies were rated as good [18-21], five as intermediate [22-26], and eight as low [27-34]. The quality of two studies [35, 36] could not be assessed due to unavailability of the manuscript but they were included in this review as they were included in the review by Elder [8]. 
Table 1 Studies included based on eligibility criteria: studies with no increases in enforcement activities or with statistical models to account for those increases

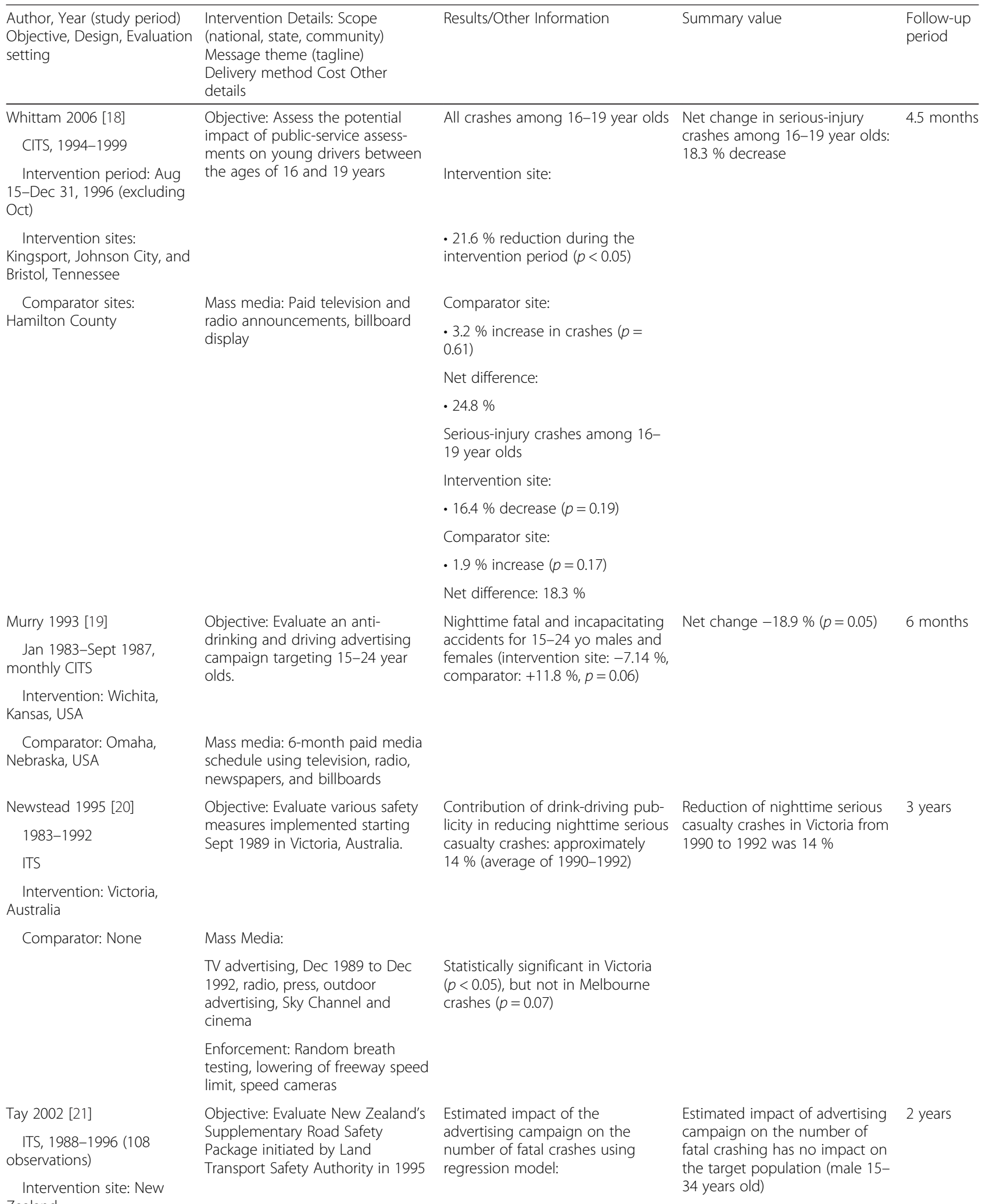


Table 1 Studies included based on eligibility criteria: studies with no increases in enforcement activities or with statistical models to account for those increases (Continued)

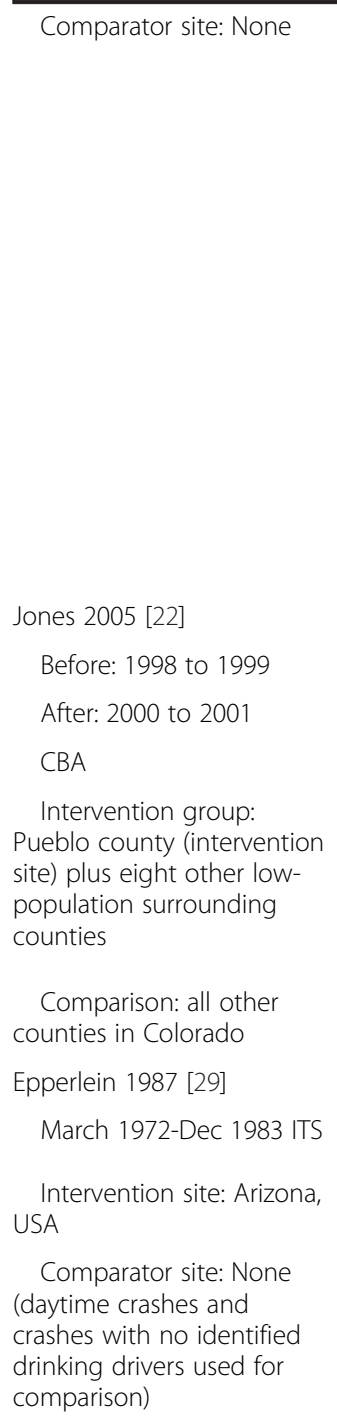

Media campaign: TV, mainly targeting

18-24 year olds

Enforcement:

Speed cameras, advanced speed detectors, compulsory breath testing

Objective: Evaluate "Smart Roads" program in Pueblo, Colorado aimed at drivers aged 21-34.

Mass media:

Television, radio, and newspaper advertisements, billboards, bumper stickers, bus station banners, other collaterals)

Workplace initiative education program.

Objective: Evaluate the effect of crackdown on drinking drivers in Arizona

Mass media:

Television, print, and radio advertisements, billboards, posters, bumper stickers (March 1982)

Enforcement:Stricter DWI legislation Increasing the minimum drinking age (August 1982)

Zampetti 2013 [34]

Before: Jun-Aug 2003

After: Jun-Aug 2008

CBA

Intervention period: 2003-2008

Intervention sites: 20 municipalities in the Local Health Authority 1 (LHA1) area in Campania, Italy

Objective: To verify the effect of intensive vs. basic road safety education programs on the incidence and severity of nonfatal road injuries (NFRTI) stations, in bars and meeting places. Dispatch of brochures,
- Male drivers between 35 and 54: $29.91 \%$ decrease

- Female drivers between 15 and 24: $40.21 \%$

- Female drivers between 25 and 34: $70.04 \%$

- No impact on young male drivers (15-34)

Estimated impact of the program before and after implementation of the campaign:

- Male drivers: -32.9 \% (15-24yo) to $+4.7 \%$ (55 years and older)

Female drivers: $-56.8 \%$ (25-34 \%) to $-26.7 \%$ (55 years and older)

Nighttime injury crashes decreased by $39 \%$ in the intervention counties, whereas it increased by $3.3 \%$ in the control counties $(p<0.0001)$

Nighttime single-vehicle crashes decreased by $24.8 \%$ in the intervention counties, whereas there was a $4.0 \%$ increase in the control counties $(p=0.01)$

Impact estimates of the antidrunk-driving publicity campaigns of March, 1982

- Nighttime fatal crashes -26.8\% (pre-intervention mean/month. 724)

- Daytime fatal crashes -10.6\% (pre-intervention mean/month. 1633)

Net change: $-16.2 \%$

- Drinking drivers in crashes $-14.0 \%$ (pre-intervention mean/ month. 1036)

- Non-drinking drivers in crashes $-0.8 \%$ (pre-intervention mean/ month. 11345)

Net change: $13.2 \%$

The number of NFRTI

- Before: 907,

After: 755

Incidence of injuries in the basic campaigns (8 municipalities)

Publicity campaigns: Billposting on • Difference in incidence of injuries public transport, bus stops, train $\quad-0.4$ per 1,000 (2003 (before) 1.1, pamphlets, and posters 2008 (after) 0.7)
Nighttime single-vehicle crashes: 4 years net change $28.8 \%$
Nighttime fatal crashes (net 22 months change): $-16.2 \%$
Difference in incidence of NFRTI 5 years in the basic site: $-0.04 \%$ $(p=0.05)$ 
Table 1 Studies included based on eligibility criteria: studies with no increases in enforcement activities or with statistical models to account for those increases (Continued)

\begin{tabular}{|c|c|c|c|}
\hline \multirow[t]{3}{*}{ No comparator site } & $\begin{array}{l}\text { Mass media: press conferences, } \\
\text { articles in local papers, radio/ } \\
\text { television interviews, and the } \\
\text { LHA1 web site }\end{array}$ & \multicolumn{2}{|l|}{$\begin{array}{l}\text { - Incidence of injuries in the } \\
\text { intensive campaigns ( } 12 \\
\text { municipalities) }\end{array}$} \\
\hline & $\begin{array}{l}\text { Sites for intensified approach (12 } \\
\text { out of } 20 \text { municipalities): }\end{array}$ & \multirow[t]{2}{*}{$\begin{array}{l}\text { - Difference }-0.5 \text { per } 1,000 ; p< \\
0.001\end{array}$} & \\
\hline & $\begin{array}{l}\text { School campaigns and community } \\
\text { conferences, 1-day conference at } \\
\text { the end of school year }\end{array}$ & & \\
\hline \multirow{9}{*}{$\begin{array}{l}\text { Worden } 1975 \text { (Elder) [35] } \\
\text { May 1972-May } 1974 \\
\text { CBA } \\
\text { Intervention site: Vermont } \\
\text { Comparison site: counties } \\
\text { with no intervention }\end{array}$} & \multirow{3}{*}{$\begin{array}{l}\text { Objective: Evaluate Vermont public } \\
\text { education campaign on alcohol } \\
\text { and highway safety }\end{array}$} & \multirow{4}{*}{$\begin{array}{l}\text { The proportion of "high-risk" male } \\
\text { drivers (those who report } \\
\text { consuming three or more drinks } \\
\text { at least once a week) above } \\
0.05 \mathrm{~g} / \mathrm{dL} \text { BAC: }\end{array}$} & \multirow{3}{*}{$\begin{array}{l}\text { Drivers above } 0.05 \mathrm{~g} / \\
-158 \%\end{array}$} \\
\hline & & & \\
\hline & & & \\
\hline & \multirow{2}{*}{$\begin{array}{l}\text { Mass media: Radio, TV, drive-in } \\
\text { theater spots. }\end{array}$} & & \multirow[t]{6}{*}{ Fatal crashes: $0 \%$} \\
\hline & & \multirow{2}{*}{$\begin{array}{l}\cdot \text { At mid-campaign (May, 1973) de- } \\
\text { creased } 37 \% \text { from a baseline of } \\
10 \text { of } 48 \text { drivers to } 9 \text { of } 69 \text { (95\% } \\
\text { Cl: }-72 \% \sim+42 \% \text {; net change = } \\
-158 \%)\end{array}$} & \\
\hline & \multirow[t]{4}{*}{$\begin{array}{l}\text { Enforcement: Stayed high } \\
\text { throughout the study period }\end{array}$} & & \\
\hline & & $\begin{array}{l}\text { - Immediately following the } \\
\text { campaign (May, 1974) decreased } \\
67 \% \text { ( } 95 \% \text { Cl: -88\% -7\%; net } \\
\text { change -111\%) }\end{array}$ & \\
\hline & & $\begin{array}{l}\text { The proportion of had-been- } \\
\text { drinking to total fatal crashes de- } \\
\text { creased } 6 \% \text { from a baseline of } 9 \\
\text { of } 20 \text { to } 8 \text { of } 19 \text { ( } 95 \% \mathrm{Cl} \text { : }-54 \% \sim \\
\text { +91\%; net change } 0 \%)\end{array}$ & \\
\hline & & *Very small sample sizes & \\
\hline Cameron 1998 (Elder) [36] & \multirow{4}{*}{$\begin{array}{l}\text { Objective: Evaluation of the first } \\
\text { two years of the New Zealand } \\
\text { Supplementary Road Safety } \\
\text { Package that was introduced in } \\
\text { 1995/1996 (supplements CBT and } \\
\text { speed camera programs } \\
\text { introduced in 1993) }\end{array}$} & \multirow{2}{*}{$\begin{array}{l}\text { In 1996-1997, campaign estimated } \\
\text { to result in: }\end{array}$} & \multirow{3}{*}{$\begin{array}{l}\text { Injury crashes } \\
\text { Arm } 1 \text { (Urban): }-7 \%\end{array}$} \\
\hline $\begin{array}{l}\text { Jan 1990-June 1997, } \\
\text { quarterly }\end{array}$ & & & \\
\hline CITS & & & \\
\hline $\begin{array}{l}\text { Intervention: New } \\
\text { Zealand (crashes during } \\
\text { high alcohol consumption } \\
\text { hours) }\end{array}$ & & $\begin{array}{l}\text { - A } 33 \% \text { decrease in urban high } \\
\text { alcohol hour serious injury crashes } \\
\text { (95\% Cl: }-40 \% \sim-25 \% \text {; net } \\
\text { change }=-7 \%)\end{array}$ & Arm 2 (Rural): $-18 \%$ \\
\hline \multirow{5}{*}{$\begin{array}{l}\text { Comparator: New Zealand } \\
\text { (crashes during low alcohol } \\
\text { consumption hours) }\end{array}$} & $\begin{array}{l}\text { Mass media: primarily TV } \\
\text { advertising campaigns }\end{array}$ & \multirow{2}{*}{$\begin{array}{l}\text { - A } 32 \% \text { decrease in rural high } \\
\text { alcohol hour serious injury crashes } \\
\text { (95\% Cl: }-41 \% \sim-22 \% \text {; net } \\
\text { change }=-18 \%)\end{array}$} & \\
\hline & \multirow[t]{4}{*}{ Enforcement: Sobriety checkpoint } & & \\
\hline & & $\begin{array}{l}\text { In 1995-1996, campaign estimated } \\
\text { to result in: }\end{array}$ & \\
\hline & & $\begin{array}{l}\text { - A } 16 \% \text { decrease in urban high } \\
\text { alcohol hour serious injury crashes } \\
(95 \% \mathrm{Cl} \text { : }-24 \sim-6 \% \text {; net change } \\
=-2 \%)\end{array}$ & \\
\hline & & $\begin{array}{l}\text { A } 6 \% \text { decrease in rural high } \\
\text { alcohol hour serious injury crashes } \\
\text { (95\% Cl: }-18 \% \sim-7 \% \text {; net } \\
\text { change }=-5 \%)\end{array}$ & \\
\hline
\end{tabular}

BAC Blood Alcohol Concentration, CBA Controlled Before-After, CBT Compulsory Breath Testing, Cl Confidence Interval, CITS Controlled Interrupted Time Series, DWI Driving While Intoxicated, ITS Interrupted Time Series, LHA Local Health Authority, NFRTI Nonfatal Road Injuries, NHTSA National Highway Traffic Safety Administration, $T V$, Television, USA United States of America 
Table 2 Studies included based on eligibility criteria: studies with increases in enforcement activities but without statistical models to account for those increases

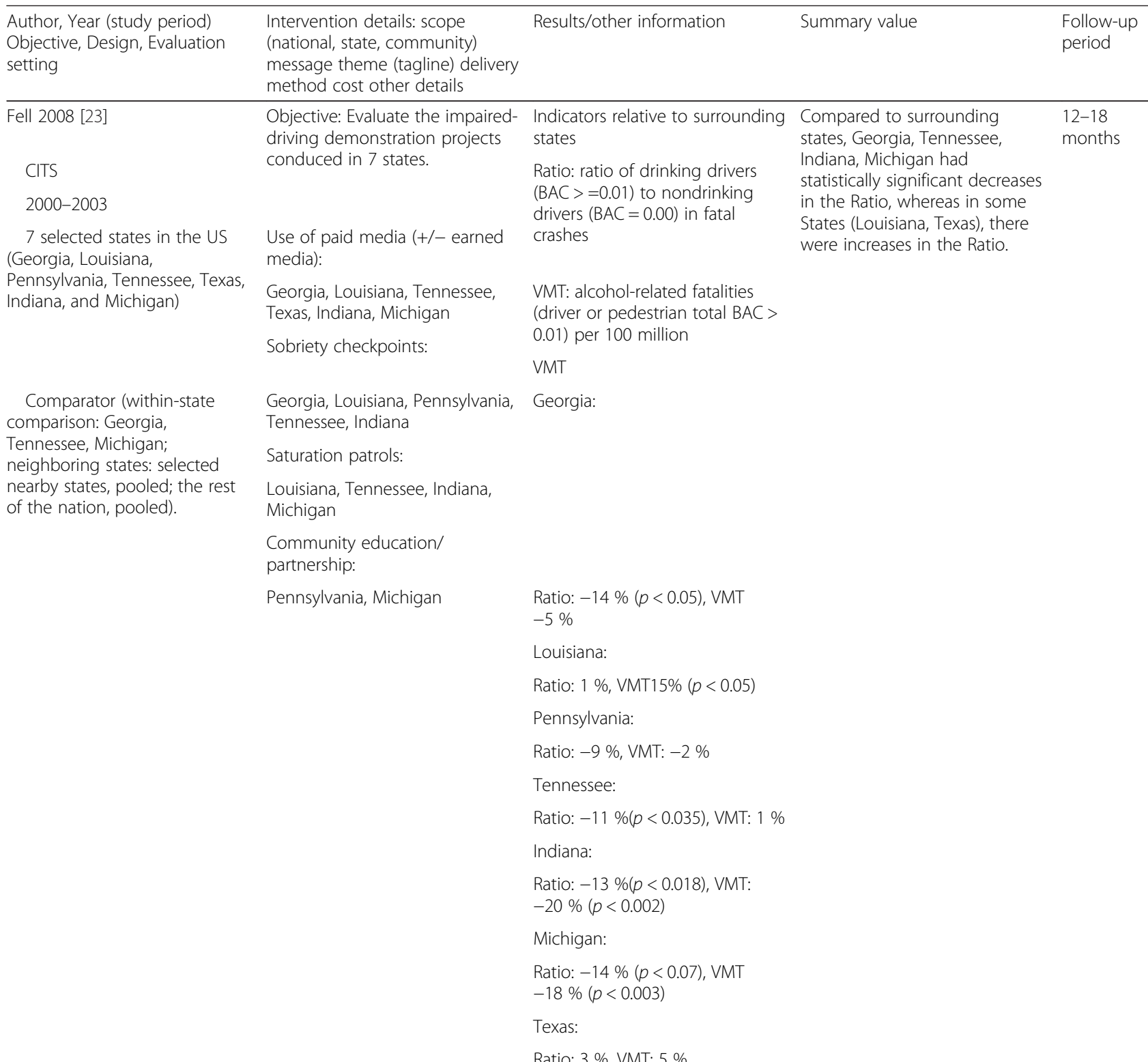

Zwicker 2007a [24]

CITS

$$
\text { 2000-2004, monthly }
$$

Intervention period: July 2003- Dec 2004

Comparison period: Jan 2000- June 2003

Intervention site: 6 counties in West Virginia

Comparator site: 49 nontargeted counties

Zwicker 2007b [25]
Objective: Evaluate the effect of the National Highway Traffic Safety Administration impaired driving high-visibility enforcement model in 2002 in West Virginia

Mass Media:

Paid media (TV)

Enforcement:

Sobriety checkpoints, saturation patrols

Objective: Evaluate Connecticut's The overall alcohol-related fatalstatewide impaired-driving publi- ity trend for the State: city and enforcement campaign $(p=0.01)$
Alcohol-related fatalities in targeted counties: - $24 \%$ $(p=0.012)$
18 months targeted counties: reduction of 0.99 lives each month. - $24 \%$

Alcohol-related fatalities in targeted countries for men 2134yo: reduction of 0.09 lives per month $(p=0.79)$

Statewide alcohol-related fatality trend: reduction of 1.6 fatalities per month $(p=0.20)$
Net change in alcohol-related fatalities in the state: $-36.4 \%$
18 months 
Table 2 Studies included based on eligibility criteria: studies with increases in enforcement activities but without statistical models to account for those increases (Continued)

\begin{tabular}{ll}
\hline Jan 2000- Dec 2004, monthly & \\
$\begin{array}{ll}\text { Intervention phase: July } & \text { Mass media: } \\
\text { 2003- Dec 2004, Comparison } & \text { Paid and earned media targeting } \\
\text { phase: Jan 2000- June } 2003 & \text { men 18-34 years old } \\
& \text { Enforcement: } \\
\text { Intervention site: Connecticut, } & \text { Sobriety checkpoint } \\
\text { USA } & \\
& \\
\text { Comparator site: } 3 & \\
\text { neighboring states }\end{array}$
\end{tabular}

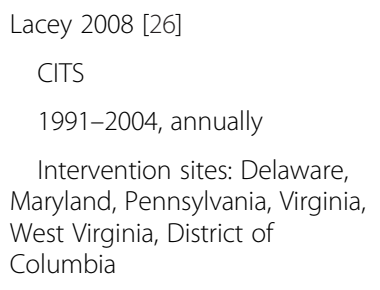

Comparator: entire nation

Agent 2002 [27]

ITS

Before intervention: 13 days around Labor day in1999-2001

Intervention: 13 days around
Labor day in 2002
Intervention site: Kentucky,
USA
Comparator: none

Solomon 2008 [28]

ITS

Intervention period: 3 weekends leading up to and around the Labor Day holiday period in 2006

Intervention: 2006

Comparaison: 2005

Intervention site: USA (nationwide)
Objective: Evaluate NHTSA Checkpoint Strikeforce program done July-December of each year, 2002-2004.

Mass Media: "Checkpoint Strikeforce. You Drink \& Drive. You Lose."

Enforcement:

Checkpoints. BAC measurements (Maryland, Delaware, and Virginia)

Objective: Document

the results of the "You Drink\& Drive.

You Lose" campaign.

Enforcement:

Checkpoints and saturated enforcement activity

\section{Mass media:}

Paid media: broadcast and cable television, radio (from 15 to 30 Aug, 2002), and outdoor billboards (15 Aug-15 Sep, 2002)

Objective: Evaluate the effect of the National 2006 Labor Day holiday campaign, "Drunk

Driving. Over the Limit. Under Arrest." Targeting age group 18 to 34 years old

Mass Media:

1. Earned media (Aug 7- Sep 10)

2. Paid media (Aug 16-20; 2327; Aug 30- Sep 3)

Enforcement:

Sobriety checkpoints, saturation patrols
Paid and earned media.
Estimated reduction of 2.604

lives each month $(p=0.01)$ for the 18 mo. following the

beginning of the campaign (Net

change: lives saved during 18

mo., $36.4 \%$ decrease)

The alcohol-related fatality trend for fatalities involving men 21 to 34 years old:

Estimated reduction in the number of fatalities by 1.568 lives each month for the $18 \mathrm{mo}$. following the beginning of the campaign $(p<0.03)$ compared to 0.16 lives per month saved in contiguous counties (Net change: 25 lives saved during 18months, $29.7 \%$ )

Alcohol-related fatal crashes in the intervention sites: $-7.1 \%$ relative to the nation as a whole $(p=0.119)$. In one State, West Virginia, the reduction was $16.7 \%(p=0.02)$ when compared to the Nation as a whole.

Number in 2002 compared to the average of the previous three years

1. The number of crashes in which alcohol and/or drugs were listed as a contributing factor or the driver was noted to be suspected of drinking: $-9 \%$ (not statistically significant)

2. The number of injuries and fatalities resulting from these crashes: $-5 \%$

1. The total number of alcoholrelated fatalities: 17,602 in 2006 compared to 17,590 in 2005 (0.07\%).

2. The number of motor vehicle fatalities for male drivers (BAC 0.01 or higher) age 18 to 34 : decreased from 5782 to 5654 $(-2.21 \%)$

3. The number of motor vehicle fatalities for male drivers (BAC 0.08 or higher) age 18 to 34 : decreased from 4996 to 4872 $(-2.48 \%)$
Net change in alcohol-related

fatalities among men 21-34

years old: $-29.7 \%$

Alcohol-related fatal crashes:

$-7.1 \%$

3 years

Alcohol/drug related crashes: -9\%

4 years

(13 days

per year)

Number of injuries and fatalities resulting from alcohol/drug

related crashes: $-5 \%$

The total number of alcohol- 4 months related fatalities: $0.07 \%$ increase (Sep-Dec (2005-2006) 
Table 2 Studies included based on eligibility criteria: studies with increases in enforcement activities but without statistical models to account for those increases (Continued)

Comparator site: none
Beck 2009 [31]
CITS
Before intervention: 1999-
2001, Intervention: 2002-2004
Intervention site: Maryland
(Pennsylvania, Delaware, West
Virginia, Virginia, District of
Columbia)
Comparator sites: Minnesota,
Oregon, and Washington
Miller 2004 [30]
ITS
Intervention (CBT): 1993
Intervention (media): 1995
Intervention (CBT
Inancement): 1996

NHTSA 2007 [32]

\section{CITS}

Before: 2001 and 2002

After: 2004 and 2005

Intervention sites: 13 Strategic Evaluation States (SES) (Alaska, Arizona, California, Florida, Georgia, Louisiana, Mississippi, Montana, New Mexico, Ohio, Pennsylvania, Texas, West Virginia)

Comparator sites: non-SES

Suriyawongpaisal 2002 [33]

ITS

March-Nov 2002, alternating months

Intervention sites: 4 of the 21 public hospitals in Bangkok, Thailand

Comparator site: None
Objective: Evaluate

the effect of the Checkpoint Strikeforce campaign

Mass Media:

Paid and earned media

Enforcement:

Sobriety checkpoints

Objective: Evaluation of three incremental CBT program approaches

Mass Media: National anti-drunkdriving campaign with hardhitting messages

Enforcement: CBT checkpoints, (Northern Region) highly visible CBT through booze busses

Objective: Evaluation of the effect on the

National Impaired Driving Crackdown Campaign targeting men 21 to 34 years old

Mass Media: paid and earned media (done nationwide). Additional advertising done in SES.

Enforcement: Sobriety checkpoints or saturation patrols in SES

Objective: Evaluate the campaign against drink-driving and enforcement efforts

Mass Media:
Net change in three-year averages before and during campaign in Maryland:

- Alcohol-related total crashes: $2.2 \%$

- Alcohol-related injury crashes: $-4.7 \%$

- Alcohol-related fatality crashes: $-2.7 \%$

- Total alcohol-related fatalities: $14.7 \%$

- Alcohol-related injured drivers: $-3.8 \%$

Mass media is estimated to have decreased in nighttime fatal or serious crashes decreased by $13.9 \%(90 \% \mathrm{Cl}=-26.1$ to -0.1$)$ nationally

Total declines in yearly average of fatal crashes for alcoholimpaired drivers from 2002 to 2005 were slightly greater for the non-SES, as compared with the SES (a $5 \%$ drop in non-SES compared to a $2 \%$ decline in SES, net decline: $3 \%$ ).

In the target group of 18-34 year-old-male drivers, the decline was greater in non-SES compared to SES (8.7\% in non-SES and $3.8 \%$ in SES).

Percentage of the traffic injury victims who were drivers with illegal BAC (0.05 or more): $14.6 \%$ increase in 9 months $(p=0.20)$
Alcohol-related total

6 years

crashes: $2.2 \%$

Total alcohol-related fatalities: $14.7 \%$

Alcohol fatalities as a percentage of total fatalities: Net change $3 \%$
Nighttime fatal or serious crashes: $-13.9 \%$
10 years

Net decline in yearly average of 5 years fatal crashes for alcoholimpaired drivers: $-3 \%$
Percentage of the traffic injury victims who were drivers with illegal BAC (0.05 or more): $14.6 \%$ increase
9 months (assessed in alternating months)
Active public education program at national scale (roadside posters; bumper; radio and TV programs or spots; public announcements; press reports), 1997 
Table 2 Studies included based on eligibility criteria: studies with increases in enforcement activities but without statistical models to account for those increases (Continued)

\section{Enforcements: \\ Highly visible sobriety check \\ points, 1999}

BAC Blood Alcohol Concentration, CBT compulsory breath testing, CITS Controlled Interrupted Time Series, ITS Interrupted Time Series, NHTSA National Highway Traffic Safety Administration, SES Strategic Evaluation States, VMT Vehicle Miles Travelled, US United States, TV Television

\section{Studies with no increases in enforcement activities or with statistical models to account for those increases}

Good quality: four studies [18-21] were included in this category. All except for one [21] had a comparator, and showed reduction in AID-related adverse outcome measures. Of those, the decrease reached statistical significance in two out of the three studies. While media campaign did not seem to show any impact in the target population (male 15-34 years old) in the study by Tay 2002 [21], it did show decreases in other age groups (male 35-54, females 15-34).

Intermediate quality: one study [22] was included in this category. Relative to the comparator counties, the intervention site had a statistically significant net decrease of nighttime single vehicle crashes by $28.8 \%$ $(-24.8 \%$ in intervention group, $+4.0 \%$ in comparison group; $p=0.01$ ) after the intervention. The study was classified as intermediate quality as the baseline characteristics in the intervention and comparator sites were not clearly addressed, and since there was a question about possible contamination of the effects and other biases due to the nature of the study (CBA studies).

Low quality: three studies were included in this category $[29,30,34]$. All three studies showed various degrees of decrease in the outcome measures, though only one [29] reached statistical significance. The studies were categorized into low quality primarily because there was no use of statistical models to assess the impact of the media campaigns.

In summary, studies that evaluated the impact of media campaigns with no increases in enforcement activities or with statistical models to account for those increases showed that the campaign resulted in a median decrease in the outcome measures by $15.1 \%$ (range 0-28.8\%).

Quality not assessed: two studies were included in this category $[35,36]$. The study by Worden et al. did not result in any net changes, but the sample size was small and the estimates were deemed to be unstable $(p>0.05)$. The study by Cameron et al. [36] comparing high alcohol hour to low alcohol hour showed a statistically significant decrease in serious injury crashes after intervention (net change $-7 \%$ in urban arm, $-18 \%$ in rural arm; $p<0.05$ for both arms).

\section{Studies with increases in enforcement activities but without statistical models to account for those increases}

Good quality: there were no studies that were considered as good quality due to the classification criteria described in the methods section.

Intermediate quality: four studies were included in this category [23-26]. The study by Fell et al. [23] included results from seven states that used publicized enforcement along with various enforcement programs. From this study, it was concluded that the programs that

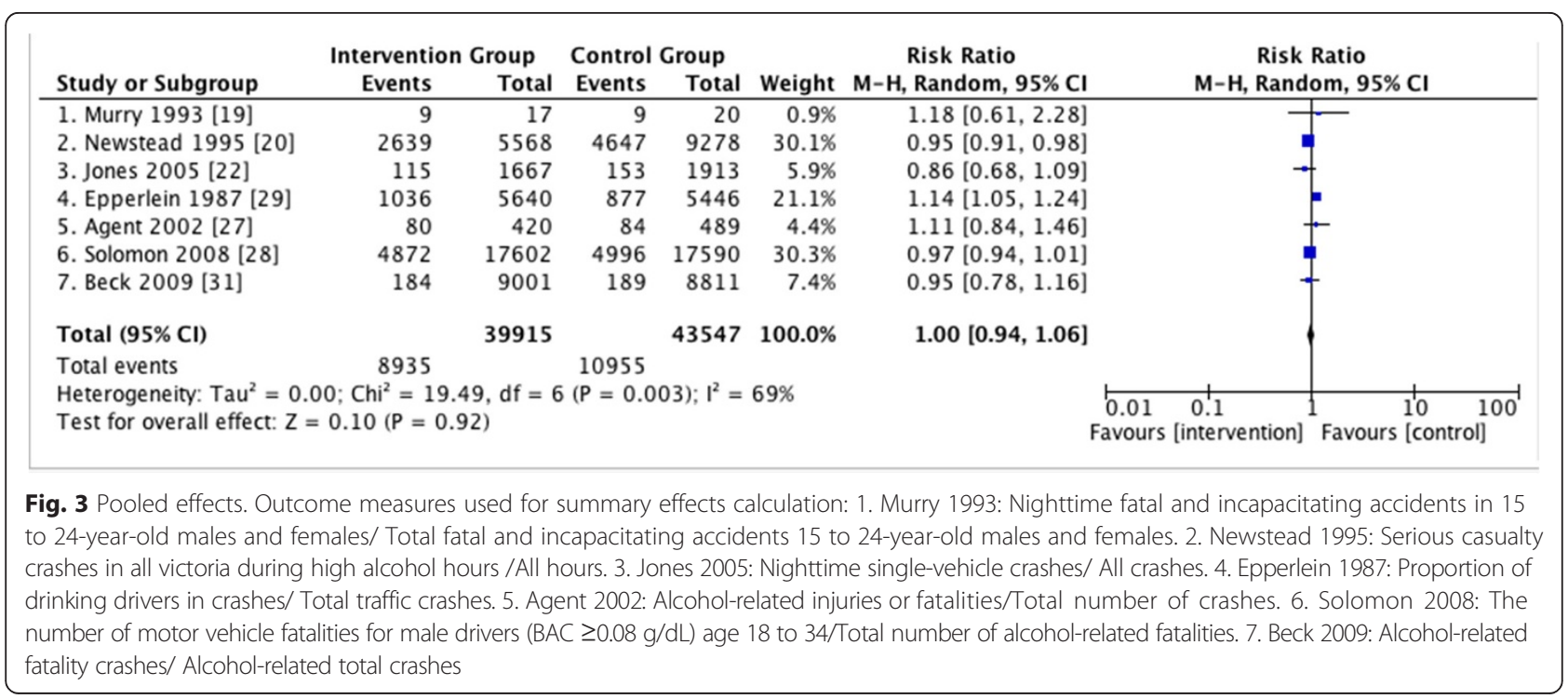


Table 3 Summary table on risk of bias of the included interrupted time series studies (excludes two studies (35, 36) that could not be assessed)

\begin{tabular}{|c|c|c|c|c|c|c|c|}
\hline ITS & $\begin{array}{l}\text { Intervention independent } \\
\text { of other changes }\end{array}$ & $\begin{array}{l}\text { Shape of the intervention } \\
\text { effect pre-specified }\end{array}$ & $\begin{array}{l}\text { Intervention } \\
\text { unlikely to } \\
\text { affect data } \\
\text { collection }\end{array}$ & $\begin{array}{l}\text { Knowledge of the } \\
\text { allocated interventions } \\
\text { adequately prevented } \\
\text { during the study }\end{array}$ & $\begin{array}{l}\text { Incomplete outcome data } \\
\text { adequately addressed }\end{array}$ & $\begin{array}{l}\text { Study free from } \\
\text { selective outcome } \\
\text { reporting }\end{array}$ & $\begin{array}{l}\text { Study free from other risks of } \\
\text { bias }\end{array}$ \\
\hline $\begin{array}{l}\text { Whittam } 2006 \\
\text { [18] }\end{array}$ & \multirow{2}{*}{$\begin{array}{l}\text { Low risk (ARIMA model } \\
\text { used and had comparator } \\
\text { site) }\end{array}$} & \multirow[t]{2}{*}{ Low risk } & \multirow[t]{2}{*}{ Low risk } & \multirow[t]{2}{*}{ Low risk } & \multirow[t]{2}{*}{ Low risk } & \multirow{2}{*}{$\begin{array}{l}\text { High risk (crash } \\
\text { data only for 16- } \\
19 \text { year olds) }\end{array}$} & \multirow[t]{2}{*}{$\begin{array}{l}\text { Low risk (has comparator site, } \\
\text { using ARIMA model) }\end{array}$} \\
\hline $\begin{array}{l}\text { Good quality } \\
\text { study }\end{array}$ & & & & & & & \\
\hline Murry 1993 [19] & \multirow{2}{*}{$\begin{array}{l}\text { Low risk (authors state that } \\
\text { data were transformed to } \\
\text { isolate the experimental } \\
\text { effect from any extraneous } \\
\text { influences) }\end{array}$} & \multirow[t]{2}{*}{ Low risk } & \multirow[t]{2}{*}{ Low risk } & \multirow[t]{2}{*}{ Low risk } & \multirow[t]{2}{*}{ Low risk } & \multirow{2}{*}{$\begin{array}{l}\text { High risk (using } \\
\text { proxy indicator, } \\
\text { using certain age } \\
\text { group only) }\end{array}$} & \multirow{2}{*}{$\begin{array}{l}\text { Low risk (using comparator } \\
\text { site, using model) }\end{array}$} \\
\hline $\begin{array}{l}\text { Good quality } \\
\text { study }\end{array}$ & & & & & & & \\
\hline $\begin{array}{l}\text { Newstead } 1995 \\
\text { [20] }\end{array}$ & \multirow{2}{*}{$\begin{array}{l}\text { Low risk (regression model } \\
\text { used to account for other } \\
\text { factors) }\end{array}$} & \multirow[t]{2}{*}{ Low risk } & \multirow[t]{2}{*}{ Low risk } & \multirow[t]{2}{*}{ Low risk } & \multirow[t]{2}{*}{ Low risk } & \multirow[t]{2}{*}{$\begin{array}{l}\text { Unclear risk (using } \\
\text { proxy indicator) }\end{array}$} & \multirow{2}{*}{$\begin{array}{l}\text { Low risk (using regression } \\
\text { model, but no comparator } \\
\text { site) }\end{array}$} \\
\hline $\begin{array}{l}\text { Good quality } \\
\text { study }\end{array}$ & & & & & & & \\
\hline Tay 2002 [21] & \multirow{2}{*}{$\begin{array}{l}\text { Low risk (used regression } \\
\text { models to exclude other } \\
\text { factors) }\end{array}$} & \multirow[t]{2}{*}{ Low risk } & \multirow[t]{2}{*}{ Low risk } & \multirow[t]{2}{*}{ Low risk } & \multirow{2}{*}{$\begin{array}{l}\text { Unclear risk (States that } \\
\text { some inconsistencies may } \\
\text { exist in the reporting as } \\
\text { done by local police) }\end{array}$} & \multirow{2}{*}{$\begin{array}{l}\text { Unclear risk (used } \\
\text { proxy measures) }\end{array}$} & \multirow[t]{2}{*}{ Low risk } \\
\hline $\begin{array}{l}\text { Good quality } \\
\text { study }\end{array}$ & & & & & & & \\
\hline Fell 2008 [23] & \multirow{2}{*}{$\begin{array}{l}\text { High risk (other } \\
\text { enforcement measures took } \\
\text { place) }\end{array}$} & \multirow[t]{2}{*}{ Low risk } & \multirow[t]{2}{*}{ Low risk } & \multirow[t]{2}{*}{ Low risk } & \multirow[t]{2}{*}{ Low risk } & \multirow[t]{2}{*}{ Low risk } & \multirow[t]{2}{*}{ Low risk } \\
\hline $\begin{array}{l}\text { Intermediate } \\
\text { quality study }\end{array}$ & & & & & & & \\
\hline $\begin{array}{l}\text { Zwicker 2007a } \\
\text { [24] }\end{array}$ & $\begin{array}{l}\text { High risk (enforcement also } \\
\text { took place) }\end{array}$ & Low risk & Low risk & Low risk & Low risk & Low risk & $\begin{array}{l}\text { Low risk (used ARIMA model } \\
\text { and applied parameters to }\end{array}$ \\
\hline $\begin{array}{l}\text { Intermediate } \\
\text { quality study }\end{array}$ & & & & & & & $\begin{array}{l}\text { model periodic fluctuations in } \\
\text { the crash rates) }\end{array}$ \\
\hline $\begin{array}{l}\text { Zwicker 2007b } \\
{[25]}\end{array}$ & $\begin{array}{l}\text { High risk (enforcement also } \\
\text { took place) }\end{array}$ & Low risk & Low risk & Low risk & Low risk & Low risk & $\begin{array}{l}\text { Low risk (contiguous county } \\
\text { data were used to remove }\end{array}$ \\
\hline $\begin{array}{l}\text { Intermediate } \\
\text { quality study }\end{array}$ & & & & & & & $\begin{array}{l}\text { factors that may have } \\
\text { obscured the effect of the } \\
\text { campaign on the trend) }\end{array}$ \\
\hline Lacey 2008 [26] & High risk (law enforcement & Low risk & Low risk & Low risk & Low risk & Low risk & Low risk (ARIMA model used) \\
\hline $\begin{array}{l}\text { Intermediate } \\
\text { quality study }\end{array}$ & & & & & & & \\
\hline $\begin{array}{l}\text { Epperlein } 1987 \\
\text { [29] }\end{array}$ & $\begin{array}{l}\text { Unclear risk (no comparator } \\
\text { site, but daytime crashes }\end{array}$ & Low risk & Low risk & Low risk & Low risk & $\begin{array}{l}\text { Unclear risk (using } \\
\text { proxy indicator) }\end{array}$ & High risk, not using model \\
\hline Low quality & $\begin{array}{l}\text { used to account for other } \\
\text { changes) }\end{array}$ & & & & & & \\
\hline Miller 2004 [30] & High risk (media campaign & Low risk & Low risk & Low risk & Low risk & Unclear risk (using & High risk (ARIMA model was \\
\hline Low quality study & $\begin{array}{l}\text { done togetner with other } \\
\text { enforcements, though }\end{array}$ & & & & & $\begin{array}{l}\text { proxy indicator, } \\
\text { fatal nighttime } \\
\text { crashes) }\end{array}$ & $\begin{array}{l}\text { Used, but evaluation of mixed } \\
\text { approaches in different areas } \\
\text { over different period) }\end{array}$ \\
\hline
\end{tabular}


Table 3 Summary table on risk of bias of the included interrupted time series studies (excludes two studies (35, 36) that could not be assessed) (Continued)

\begin{tabular}{|c|c|c|c|c|c|c|c|}
\hline & $\begin{array}{l}\text { model was used to look at } \\
\text { each interventions) }\end{array}$ & & & & & & \\
\hline Agent 2002 [27] & \multirow{2}{*}{$\begin{array}{l}\text { High risk (enforcement } \\
\text { activities also took place as } \\
\text { part of the campaign) }\end{array}$} & \multirow[t]{2}{*}{ Low risk } & \multirow[t]{2}{*}{ Low risk } & \multirow[t]{2}{*}{ Low risk } & \multirow[t]{2}{*}{ Low risk } & \multirow{2}{*}{$\begin{array}{l}\text { Unclear risk } \\
\text { (documentation } \\
\text { of alcohol use is } \\
\text { dependent on the } \\
\text { reporting officer) }\end{array}$} & \multirow[t]{2}{*}{ High risk (no model used) } \\
\hline Low quality study & & & & & & & \\
\hline $\begin{array}{l}\text { Solomon } 2008 \\
\text { [28] }\end{array}$ & \multirow[t]{2}{*}{$\begin{array}{l}\text { High risk (enforcement } \\
\text { measures also in place) }\end{array}$} & \multirow[t]{2}{*}{ Low risk } & \multirow[t]{2}{*}{ Low risk } & \multirow[t]{2}{*}{ Low risk } & \multirow[t]{2}{*}{ Low risk } & \multirow[t]{2}{*}{ Low risk } & \multirow{2}{*}{$\begin{array}{l}\text { High risk (Only looking at } \\
\text { changes in absolute numbers, } \\
\text { no application of models, no } \\
\text { comparator site) }\end{array}$} \\
\hline Low quality study & & & & & & & \\
\hline Beck 2009 [31] & \multirow{2}{*}{$\begin{array}{l}\text { High risk (enforcement also } \\
\text { took place) }\end{array}$} & \multirow{2}{*}{$\begin{array}{l}\text { High risk (point of analysis } \\
\text { not clear) }\end{array}$} & \multirow[t]{2}{*}{ Low risk } & \multirow[t]{2}{*}{ Low risk } & \multirow[t]{2}{*}{ Low risk } & \multirow[t]{2}{*}{ Low risk } & \multirow{2}{*}{$\begin{array}{l}\text { High risk (only looking at the } \\
\text { absolute number of alcohol- } \\
\text { related crashes, not using any } \\
\text { models or accounting for rates } \\
\text { in comparator sites) }\end{array}$} \\
\hline Low quality study & & & & & & & \\
\hline NHTSA 2007 [32] & \multirow{2}{*}{$\begin{array}{l}\text { High risk (enforcement also } \\
\text { took place) }\end{array}$} & \multirow[t]{2}{*}{ Low risk } & \multirow[t]{2}{*}{ Low risk } & \multirow[t]{2}{*}{ Low risk } & \multirow[t]{2}{*}{ Low risk } & \multirow[t]{2}{*}{ Low risk } & \multirow{2}{*}{$\begin{array}{l}\text { High risk (compared with non- } \\
\text { intervention sites, but no } \\
\text { model used. Unclear if other } \\
\text { factors accounted for) }\end{array}$} \\
\hline Low quality study & & & & & & & \\
\hline $\begin{array}{l}\text { Suriyawongpaisal } \\
2002[33]\end{array}$ & \multirow[t]{2}{*}{$\begin{array}{l}\text { High risk (enforcement } \\
\text { measures also used) }\end{array}$} & \multirow{2}{*}{$\begin{array}{l}\text { High risk (point of analysis } \\
\text { is not the point of } \\
\text { intervention, and not } \\
\text { clearly stated why the } \\
\text { data points were selected) }\end{array}$} & \multirow[t]{2}{*}{ Low risk } & \multirow{2}{*}{$\begin{array}{l}\text { High risk (hospital staff } \\
\text { of the study sites were } \\
\text { not blinded, and could } \\
\text { have affected how they } \\
\text { collected data) }\end{array}$} & \multirow{2}{*}{$\begin{array}{l}\text { High risk (not sure what } \\
\text { proportion of cases were } \\
\text { missed in each period, } \\
\text { data collection dependent } \\
\text { on hospitals enrolled) }\end{array}$} & \multirow[t]{2}{*}{ Unclear risk } & \multirow{2}{*}{$\begin{array}{l}\text { High risk (the study did not } \\
\text { account for other changes that } \\
\text { could have affected the } \\
\text { outcome) }\end{array}$} \\
\hline Low quality study & & & & & & & \\
\hline
\end{tabular}

ARIMA, Autoregressive Moving Average Model; ITS, Interrupted Time Series; NHTSA, National Highway Traffic Safety Administration 
Table 4 Summary table on risk of bias of the included controlled before after studies (excludes two studies [35, 36] that could not be assessed)

\begin{tabular}{|c|c|c|c|c|c|c|c|c|c|}
\hline$\overline{\mathrm{CBA}}$ & $\begin{array}{l}\text { Allocation } \\
\text { sequence } \\
\text { generation }\end{array}$ & $\begin{array}{l}\text { Allocation } \\
\text { adequately } \\
\text { concealed }\end{array}$ & $\begin{array}{l}\text { Baseline } \\
\text { outcome } \\
\text { measurements } \\
\text { similar }\end{array}$ & $\begin{array}{l}\text { Baseline } \\
\text { characteristics } \\
\text { similar }\end{array}$ & $\begin{array}{l}\text { Incomplete } \\
\text { outcome data } \\
\text { adequately } \\
\text { addressed }\end{array}$ & $\begin{array}{l}\text { Knowledge of the } \\
\text { allocated } \\
\text { interventions } \\
\text { adequately } \\
\text { prevented }\end{array}$ & $\begin{array}{l}\text { Study adequately protected against } \\
\text { contamination }\end{array}$ & $\begin{array}{l}\text { Study fee } \\
\text { from selective } \\
\text { outcome } \\
\text { reporting }\end{array}$ & $\begin{array}{l}\text { Study free from other } \\
\text { risks of bias }\end{array}$ \\
\hline $\begin{array}{l}\text { Jones } 2005 \\
{[22]}\end{array}$ & High risk & High risk & Low risk & Unclear & Unclear & Low risk & \multirow{2}{*}{$\begin{array}{l}\text { Unclear risk (selected Pueblo and } \\
\text { surrounding counties as intervention } \\
\text { sites, but possibility of contamination } \\
\text { remains) }\end{array}$} & \multirow{2}{*}{$\begin{array}{l}\text { Unclear risk } \\
\text { (using } \\
\text { surrogate } \\
\text { indicator) }\end{array}$} & \multirow{2}{*}{$\begin{array}{l}\text { Unclear risk (not sure if it } \\
\text { has accounted for other } \\
\text { changes during before/ } \\
\text { after) }\end{array}$} \\
\hline $\begin{array}{l}\text { Intermediate } \\
\text { quality study }\end{array}$ & & & & & & & & & \\
\hline $\begin{array}{l}\text { Zampetti } \\
2013[34]\end{array}$ & \multirow[t]{2}{*}{ High risk } & \multirow[t]{2}{*}{ High risk } & \multirow[t]{2}{*}{ Low risk } & \multirow[t]{2}{*}{ Unclear } & \multirow[t]{2}{*}{ Unclear } & \multirow[t]{2}{*}{ Low risk } & \multirow[t]{2}{*}{ Unclear (due to nature of intervention) } & \multirow{2}{*}{$\begin{array}{l}\text { Unclear (using } \\
\text { proxy } \\
\text { indicator) }\end{array}$} & \multirow{2}{*}{$\begin{array}{l}\text { High risk (has not taken } \\
\text { into account other } \\
\text { changes during study } \\
\text { period) }\end{array}$} \\
\hline $\begin{array}{l}\text { Low quality } \\
\text { study }\end{array}$ & & & & & & & & & \\
\hline
\end{tabular}


experienced significant reductions included the use of paid media to publicize the enforcement, using a statewide model rather than selected portions of the state, and the use of highly visible and frequent sobriety checkpoints [23]. The remaining three assessed the results of projects that used a combination of media campaigns and sobriety checkpoints as enforcement measures. All three studies used alcohol-related fatal crashes as outcome measures and showed reduction, though the study by Lacey et al. [26] did not reach statistical significance.

Low quality: five studies were included in this category [27, 28, 31-33]. The intervention by Agent et al. [27] and Solomon et al. [28] were similar in that they both involved targeted media campaigns and enforcement measures surrounding the Labor day holiday. Both showed some degree of reduction in the outcome measures, although there were differences in the outcomes measured (alcohol-related fatalities during the year preand post- intervention versus alcohol-related crashes and injuries 13 days around Labor day). The study by Suriyawongpaisal [33] showed significant increase in the percent of drivers among traffic injury victims with illegal BAC $(\geq 0.05 \mathrm{~g} / \mathrm{dL})$ among traffic injury cases $(30.0$ to $44.6 \%$, net change $+14.6 \%$ ). However, it should also be noted that the methodology of this study was different from other studies in that: 1) the study was conducted after 8 months of law enforcement and 2 years of active public education program without baseline figures prior to the intervention, 2) the results did not take into account the changes in overall number of traffic accidents during the study period, and 3) data collection was done during a pre-defined period, therefore, prone to reporting bias.

In summary, studies that measured the effects of concomitant enforcement activities in addition to media campaigns showed a median reduction of $8.6 \%$ (range -36.4 to $+14.6 \%)$ in their outcome measures.

\section{Summary effect measures}

A total of seven studies $[19,20,22,27-29,31]$ were included in the summary effect measures calculation, and the results are summarized in Fig. 1. Results of pooled analysis of the seven studies did not show any improved risk of alcohol-related injuries or fatalities from the intervention $(\mathrm{RR}=1.00,95 \% \mathrm{CI}=0.94-1.06)$.

\section{Discussion}

While results from individual studies suggested reduction in their respective outcome measures after intervention, reduction was not observed in the pooled analysis of relative risk of alcohol-related injuries or fatalities by media campaigns. This is likely due to the large heterogeneity observed in the methodology of the media campaigns, the follow-up methods, and the outcome measures used: Some studies had concomitant enforcement measures along with the media campaigns, and not all studies conducted analyses to examine the effects from media campaigns only; variety in the duration and intensity of media campaigns were observed; proxy measures were used in some studies for alcoholrelated fatal crashes, and the presentation of outcome varied from mean cases per month generated from a model to raw figures based on changes in annual cases pre- and post- intervention. An attempt was made to include only those studies that allowed comparison of similar outcome measures (e.g. risk of alcohol-related fatalities over all crashes) in the summary effects calculation. Regardless, heterogeneity remained among the included studies.

\section{Messages used in media campaigns}

Six out of the eight studies that assessed the effects of media campaigns independently showed statistically significant differences after intervention [19-22, 29, 30]. Some of these studies have attributed their success in their campaigns to having a message that emphasized the consequences of alcohol-induced driving. Examples include messages such as "Drunk Drivers Should Be Barred" [29] or "DUI: the $\$ 8866$ Hangover" [22]. The later indicates the true cost of DUI as the sum of increasing insurance costs, lawyer fees, fines, and other expenses [22]. Miller et al. [30] did not describe the details of the media campaign, but they did state that the campaign was "harder hitting and more intensive" compared to previous campaigns. The purpose of the study by Tay et al. [21] was to examine the impact of a fear-based advertising campaign. While their analysis showed that the intervention was effective for certain age groups, it did not seem to influence the main target population, which was male 15-34 years old. Therefore, the authors concluded that, "an appeal to the emotion of fear will evoke different responses from different segments of an audience".

This study built on the study by Elder 2004 [8], and added an additional decade of research literature. There are several limitations to this study: First, some eligible reports may have been missed due to language. Most of the studies included in this review are coming from English-speaking developed countries, namely, the US, Australia, and New Zealand. Therefore, the results may not be generalizable to low- and middle- income countries where traffic regulations and driving practices may be different. Second, most of the studies did not describe the interventions well enough for the reader to understand the intensity of mass media campaigns. This resulted in challenges and ambiguities in extracting data. Third, heterogeneity was large among the included 
studies, including settings, methods, and outcome measures used, as described earlier.

Although the pooled analysis did not show any evidence that media campaigns reduce the risk of alcohol-induced fatalities, we cannot conclude that media campaigns have no effect altogether given the large heterogeneity seen among studies. It is surprising that only a limited number of good quality study could be added to update the review of Elder et al. [8], considering the wider availability of options to conduct media campaigns. In addition, drink driving remains to be one of the leading causes of death in many countries and millions of dollars have been spent on mass media campaigns to reduce them.

\section{Conclusions}

Heterogeneity in methodology, interventions and outcome measures were observed among the included studies and pooled analysis did not show evidence that media campaigns reduced the risk of alcohol-related fatalities.

More studies are required to find how mass media could be made more cost-effective in terms of timing and location, target audience, and message and campaign characteristics. In addition, more studies from low- and middle-income countries are needed where the majority of road traffic deaths occur.

\section{Competing interests}

The authors declare that they have no competing interests.

\section{Authors' contributions}

First, RY conceptualized the systematic review and developed the search criteria. Then, both reviewers RY and MK independently examined titles, abstracts and key works of citations from many electronic databases for eligibility. Finally, they drafted the manuscript together. Both authors read and approved the final manuscript.

\section{Acknowledgements}

We thank Nicholas Mays and Mark Petticrew from the London School of Hygiene and Tropical Medicine for their feedback. We also thank the 2012 cohort of Doctor of Public Health students at London School of Hygiene and Tropical Medicine for their inputs. No financial disclosures were reported by the authors of this paper.

Received: 19 February 2015 Accepted: 24 July 2015

Published online: 04 September 2015

\section{References}

1. World Health Organization. Global status report on road safety 2013. Geneva. 2013.

2. World Health Organization. World report on traffic injury prevention. Geneva. 2004.

3. Noar SM. A 10-year retrospective of research in health mass media campaigns: where do we go from here? J Heal Commun Int Perspect. 2006;11:21-42

4. Snyder LB, Hamilton MA. A meta-analysis of U.S. Health campaign effects on behavior: emphasize enforcement, exposure, and new information, and beware the secular trend. In: Public health communication: evidence for behavior change. Mahwah, NJ: Erlbaum; 2002. p. 357-84.

5. Derzon J, Lipsey M. A meta-analysis of the effectiveness of masscommunication for changing substance-use knowledge, attitudes, and behaviour. In: Crano W, Burgoon M, editors. Mass media and drug prevention: classic and contemporary theories and research. Mahwah, NJ: Ehlbaum; 2002. p. 231-58.

6. Cheng H, Kitler P, Lee N. Social marketing for public health: global trends and success stories. Sudbury, Massachusetts: Jones and Bartlett Publishers; 2010. p. 385.

7. Snitow S, Brennan L. Reducing drink driving road deaths: integrating communication and social policy enforcement in Australia. In: Cheng H, Kotler P, Lee NR, editors. Social marketing for public health: global trends and success stories. Boston: Jones and Bartlett Publishers; 2011. p. 383-404.

8. Elder RW, Shults RA, Sleet DA, Nichols JL, Thompson RS, Rajab W. Effectiveness of mass media campaigns for reducing drinking and driving and alcohol-involved crashes: a systematic review. Am J Prev Med. 2004;27:57-65.

9. Edelman D, Salsberg B. Beyond paid media: marketing's new vocabulary. 2010. p. 1-8.

10. Gil de Zúñiga $\mathrm{H}$, Jung N, Valenzuela S. Social media use for news and individuals' social capital, civic engagement and political participation. J Comput Commun. 2012;17:319-36.

11. Gold J, Pedrana A, Sacks-Davis R, Hellard M, Chang S, Howard S, et al. A systematic examination of the use of online social networking sites for sexual health promotion. BMC Public Health. 2011;11.

12. Hamm MP, Shulhan J, Williams G, Milne A, Scott SD, Harling L. A systematic review of the use and effectiveness of social media in child health. BMC Pediatr. 2014;14.

13. Livingston J, Tugwell A, Korf-Uzan K, Cianfrone M, Coniglio C. Evaluation of a campaign to improve awareness and attitudes of young people towards mental health issues. Soc Psychiatry Psychiatr Epidemiol. 2013:48:965-73.

14. Goss CW, Van Bramer LD, Gliner JA, Porter TR, Roberts IG, DiGuiseppi C. Increased police patrols for preventing alcohol-impaired driving. Cochrane Database Syst Rev. 2008;4:CD005242.

15. McLean A, Kloeden C, McCaul K. Drink-driving in the general night-time driving population, Adelaide 1989. Aust J Public Health. 1991;15:190-3.

16. Voas R, Romano E, Peck R. Validity of surrogate measures of alcohol involvement when applied to nonfatal crashes. Accid Anal Prev. 2009;41:522-30.

17. Risk of Bias - EPOC specific http://epoc.cochrane.org/sites/ epoc.cochrane.org/files/uploads/ Suggested\%20risk\%20of\%20bias\%20criteria\%20for\%20EPOC\%20reviews.pdf

18. Whittam K, Dwyer W, Simpson P. Effectiveness of a media campaign to reduce traffic crashes involving young drivers. J Appl Soc Psychol. 2006;36:614-28.

19. Murry J, Stam A, Lastovicka JL. Evaluating and anti-drinking and driving advertising campaign with a sample survey and time series intervention analysis. J Am Stat Assoc. 1993;88:50-6.

20. Newstead S, Cameron M, Gantzer S, Vulcan P. Modelling of some major factors influencing road trauma trends in Victoria 1989-93. 1995.

21. Tay R, Ozanne L. Who are we scaring with high fear road safety advertising campaigns? Asia Pacific J Transp. 2002;4:1-12.

22. Jones R, Rodriguez-Iglesias C, Cyr E. Evaluation of Pueblo County. Springfield: Colorado's Smart Roads Project; 2005.

23. Fell JC, Tippetts AS, Levy M. Evaluation of seven publicized enforcement demonstration programs to reduce impaired driving: Georgia, Louisiana, Pennsylvania, Tennessee, Texas, Indiana, and Michigan. Ann Adv Automot Med. 2008:52:23-38.

24. Zwicker T, Chaudhary N, Solomon M, Siegler J, Meadows J. West Virginia's impaired driving high visibility enforcement campaign, 2003-2005. Virginia: Springfield; 2007.

25. Zwicker T, Chaudhary N, Maloney S, Squeglia R. Conneticut's 2003 impaireddriving high-visibility enforcement campaign. Virginia: Springfield; 2007.

26. Lacey J, Kelly-Baker T, Brainard K, Tippets S, Lyakhovich M. Evaluation of the checkpoint strikeforce program. Washington DC. 2008.

27. Agent KR, Green ER, Langley RE. Evaluation of Kentucky's "You Drink and Drive. You Lose" Campaign. 2002. p. 31.

28. Solomon MG, Hedlund J, Haire E, Chaffe RHB. The 2006 National Labor Day impaired driving enforcement crackdown: drunk driving. Over limit. Under arrest. Washington DC. 2008.

29. Epperlein T. Initial deterrent effects of the crackdown on drinking drivers in the state of Arizona. Accid Anal Prev. 1987;19:285-303.

30. Miller T, Blewden M, Zhang J. Cost savings from a sustained compulsory breath testing and media campaign in New Zealand. Accid Anal Prev. 2004;36:783-94. 
31. Beck KH. Lessons learned from evaluating Maryland's anti-drunk driving campaign: assessing the evidence for cognitive, behavioral, and public health impact. Health Promot Pract. 2009;10:370-7.

32. National Highway Traffic Safety Administration. Evaluation of the national impaired driving high-visibility enforcement campaign: 2003-2005. 2007.

33. Suriyawongpaisal P, Plitapolkarnpim A, Tawonwanchai A. Application of 0.05 per cent legal blood alcohol limits to traffic injury control in Bangkok. J Med Assoc Thai. 2002;85:496-501.

34. Zampetti R, Messina G, Quercioli C, Vencia F, Genco L, Bartolomeo LD, et al. Nonfatal road traffic injuries: can road safety campaigns prevent hazardous behavior? An Italian experience. Traffic Inj Prev. 2013;14:261-6.

35. Worden J, Waller J, Riley T. The Vermont public education campaign in alcohol and highway safety: a final review and evaluation. Waterbury; CRASH report I-5. 1975.

36. Cameron M, Vulkan P. Evaluation review of the supplementary road safety package and its outcomes during the first two years. New Zealand: Auckland; 1998

\section{Submit your next manuscript to BioMed Central and take full advantage of:}

- Convenient online submission

- Thorough peer review

- No space constraints or color figure charges

- Immediate publication on acceptance

- Inclusion in PubMed, CAS, Scopus and Google Scholar

- Research which is freely available for redistribution 